\title{
Impact of El Niño on the foraging behavior of female northern elephant seals
}

\author{
Daniel E. Crocker ${ }^{1, *}$, Daniel P. Costa ${ }^{2}$, Burney J. Le Boeuf ${ }^{2}$, Paul M. Webb ${ }^{3}$, \\ Dorian S. Houser ${ }^{1}$ \\ ${ }^{1}$ Department of Biology, Sonoma State University, 1801 East Cotati Road, Rohnert Park, California 94928, USA \\ ${ }^{2}$ Department of Biology, Institute of Marine Sciences, University of California, Santa Cruz, California 95064, USA \\ ${ }^{3}$ Department of Biology, Roger Williams University, One Old Ferry Road, Bristol, Rhode Island 02809, USA
}

\begin{abstract}
Our aim was to examine the foraging behavior of northern elephant seals Mirounga angustirostris during the 1997-98 El Niño and compare it to foraging in others years. Given their deep diving and spatial distribution, their immediate response to a severe El Niño was expected to give insight into the timing, scale and magnitude of El Niño Southern Oscillation impacts on a large marine predator. Time-depth records and Argoslinked satellite tracks were obtained from adult females departing on post-breeding foraging migrations from 1990 to 1999, including females foraging during the 1998 El Niño. Rates of mass gain and trip duration were recorded for females from 1983 to 1999. Movement tracks of females in 1998 were similar to those observed in non-El Niño years. Rate of mass gain at sea was $0.29 \pm 0.36 \mathrm{~kg}$ $\mathrm{d}^{-1}$ in 1998, the lowest measured since 1983. Marked declines in the mass gain rate of females were noted in severe El Niño years, but not in moderate El Niño years. Females increase spring foraging trip duration to compensate for decreases in foraging success. In 1998, the frequency distribution and temporal pattern of dive shapes suggested reduced residence time in prey patches and increased travel time between patches and these parameters showed a strong relationship with rates of mass gain. Our data confirm that the immediate ecological impact of the 1997-98 El Niño was not limited to the near-shore coastal margin, but extended far out into the North Pacific Ocean.
\end{abstract}

KEY WORDS: El Niño $\cdot$ Foraging $\cdot$ Seals $\cdot$ Water temperature Prey patches

Resale or republication not permitted without written consent of the publisher

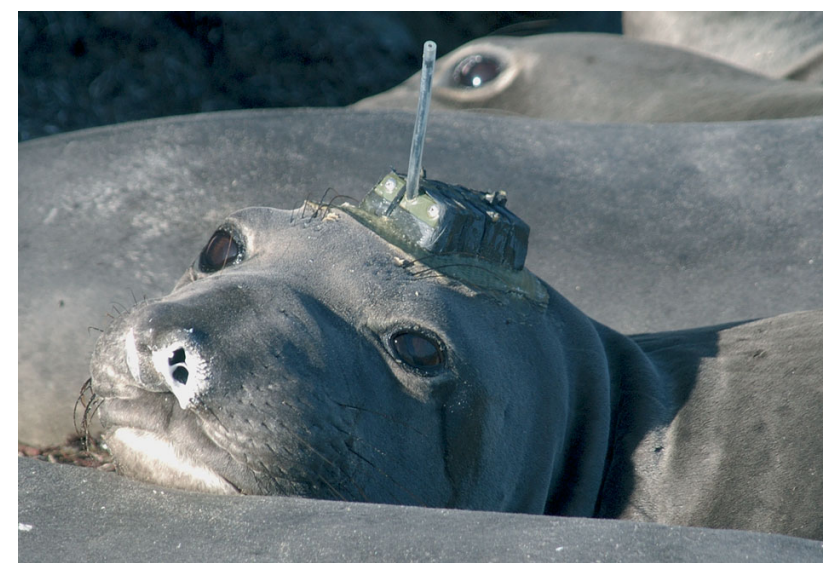

Northern elephant seal females exhibited dramatic changes in foraging behavior during the $1998 \mathrm{El} \mathrm{Niño,} \mathrm{including} \mathrm{reduced}$ foraging success and residence time in prey patches.

Photo by Daniel P. Costa

\section{INTRODUCTION}

El Niño is a periodic, meteorological and oceanographic phenomenon that occurs in the eastern tropical Pacific Ocean in association with atmospheric forcing known as the Southern Oscillation. The El Niño Southern Oscillation (ENSO) affects both the Pacific marine environment and terrestrial systems worldwide, making it one of the strongest natural disturbances of ecosystems. The 1997-98 El Niño was, by some measures, the strongest of the 20th century (Kerr 1998, McPhadden 1999, Enfield 2001). The widespread biological impacts of El Niño events are not well understood. Dramatic impacts on reproductive 
parameters of seabirds and fisheries stocks have been described for previous ENSO events (Barber \& Chavez 1983, 1986, Schreiber \& Schreiber 1984), as well as dramatic large-scale changes in the distribution of some species (Arntz et al. 1991, Raskoff 2001). Major changes in structure and productivity of the North Pacific sub-tropical gyre have been attributed to ENSO events (Karl et al. 1995). Although studies of ENSO impacts have tended to focus on low latitude effects or effects within coastal upwelling zones (e.g. Brodeur \& Percy 1992), significant time-lagged ecological changes at higher latitudes (Heywood et al. 1985, Brinton et al. 1987) and concurrent impacts on wide-ranging pelagic predators (e.g. Le Boeuf \& Reiter 1991) suggest that the ecological effects of ENSO extend far beyond the tropical ocean. We examined the foraging behavior of one such predator, the northern elephant seal Mirounga angustirostris, to see if foraging behavior and success varied with ENSO conditions and to give insight into the mechanisms underlying any apparent foraging difficulties.

The 1982-83 El Niño had a severe impact on some Pacific coast pinnipeds (Trillmich \& Ono 1991). In northern elephant seals, the following effects suggested that they had foraging difficulties: increased foraging trip duration in females, reduced survivorship of pups born in 1983 to Ages 2, 3 and 4 yr, low reproductive success of the 1983 cohort as measured by females primiparous at Age 3 and $4 \mathrm{yr}$, and reduced survival of breeding males from 1983 to 1984 (Le Boeuf \& Reiter 1991). Subsequent investigations revealed that female northern elephant seals are wide-ranging pelagic predators, foraging at great depths (Le Boeuf et al. 2000). During the 2 to 3 mo foraging period following lactation, females range across a wide area of the northeastern Pacific - from 38 to $58^{\circ} \mathrm{N}$, and from near the coast of the continent at $125^{\circ} \mathrm{W}$ to as far west as $173^{\circ} \mathrm{E}$ - diving nearly continuously to mean depths in the range of 400 to $700 \mathrm{~m}$. Adult female elephant seals feed predominantly on cephalopod prey that inhabits epi-, meso-, or bathypelagic oceanic zones (Antonelis et al. 1987, 1994). Given their deep diving pattern, wide spatial distribution and long foraging periods, we would expect El Niño events to have lesser impacts on female northern elephant seals than on coastal pinnipeds. Furthermore, we would expect impacts based on El Niño associated reductions in productivity to be time lagged for apex predators, with the duration of the lag increasing with trophic level (Watters et al. 2003). An immediate response to a severe El Niño should provide important clues on the temporal and spatial scales on which ecological effects occur, the impact of rapid ecosystem change on a large marine predator, and behavioral responses to potential reductions in prey availability.

\section{MATERIALS AND METHODS}

Subjects and instruments. Time-depth recorders (Mk 3 TDR, Wildlife Computers) were deployed on 35 adult females, 6 to $8 \mathrm{yr}$ of age, at Año Nuevo, California, just prior to their departure after breeding in 1990, 1991, 1995, 1996, 1998 and 1999. The seals were immobilized with a mixture of teletamine hydrochloride/ zolazepam hydrochloride ( $1 \mathrm{mg} \mathrm{kg}^{-1}$; Telazol) administered intramuscularly by hand injection. Subsequent injections of ketamine hydrochloride were administered by syringe intravenously when necessary (Briggs et al. 1975). Dive recorders were attached to the pelage on the dorsal midline above the shoulders (Le Boeuf et al. 1988) with a stainless steel hose-clamp and nylon netting attached to the back of the head with marine epoxy (Evercoast Ten-set, Fibre-Evercoat). Dive recorders were programmed to sample depth every $30 \mathrm{~s}$. In 1996, 1998 and 1999, instruments also sampled water temperature concurrently with depth. Water temperature sensors had a time-lag of $\sim 30 \mathrm{~s}$ and temperature data were offset by $30 \mathrm{~s}$ to account for this time lag (Boehlert et al. 2001). Half-watt ST-6 satellite platform transmitter terminals or PPTs (Telonics, Mesa, AZ) were deployed on 6 to 8 yr old females in 1995, 1996, 1998 and 1999. PTTs measuring $6.5 \times 13.7 \times$ $4.5 \mathrm{~cm}$ and weighing $458 \mathrm{~g}$ were attached to the back of the head using marine epoxy and nylon mesh (Le Bouef et al. 2000). The PTTs transmitted every $34 \mathrm{~s}$. The females were rolled into a nylon tarpaulin and weighed with a $1000 \pm 1 \mathrm{~kg}$ tension dynamometer mounted on an aluminum tripod. Blubber thickness was determined with an ultrasound scanner (Scanoprobe, Ithaca) and standard length and axillary girth were measured with flexible tape. Dorsal, lateral, and ventral blubber thickness, length and girth were measured at 6 locations along the seal's long axis. Based on these measurements, body composition was estimated for each female using the truncated cones method (Gales \& Burton 1987, Webb at al. 1998, Le Boeuf et al. 2000, Crocker et al. 2001). When the seals returned to the rookery the instruments were removed, leaving the epoxy mounts to fall off during the annual molt, and female weights and measures were taken once more.

Diving behavior of females from 1990 to 1996 and satellite tracks from 1995 and 1996 have been summarized in other investigations (Le Boeuf et al. 1993, 1996, 2000, Crocker et al. 1997). Trip duration and rates of mass gain were compared with data from females that carried instruments on spring foraging migrations in 1983 to 1996 and in 1999 ( $\mathrm{n}=64)$ (Le Boeuf \& Reiter 1991, Le Boeuf et al. 1996, 2000, our study).

For statistical comparisons, each year was classified as either a 'no', 'weak' or 'strong' El Niño year based on an index derived from observed sea surface tem- 
perature (SST) anomalies. The index used was from the Japan Meteorological Agency (JMA) (ftp://www. coaps.fsu.edu/pub/JMA_SST_Index). The index is a 5 mo running mean of spatially averaged SST anomalies from the tropical Pacific: $4^{\circ} \mathrm{S}$ to $4^{\circ} \mathrm{N}$, $150^{\circ} \mathrm{W}$ to $90^{\circ} \mathrm{W}$. The peak index value from October through December prior to the spring foraging migration was used. The year was classified as 'no El Niño' if the index value was less than $1.0^{\circ}$, as a 'weak El Niño' if the index was between $1.0^{\circ}$ and $2.0^{\circ}$, and as a 'strong El Niño' if the index was greater than $2.0^{\circ}$. Strong El Niño years included 1983 and 1998. Weak El Niño years included 1987, 1988 and 1992. No El Niño years included 1984 to 1986, 1989 to 1991 and 1993 to 1997.

Movement analysis. All Argos location qualities except class $\mathrm{Z}$ were included in the analysis. Locations were filtered to exclude positions yielding unreasonable transit speeds of over $3.0 \mathrm{~m} \mathrm{~s}^{-1}$ between locations. Great-circle distances between locations were calculated with spherical trigonometry (Congleton 1980). Foraging trip duration was the time elapsed from a seal's departure to its return to land, as determined from the TDR data. Maximum track distance was calculated as the great circle distance between the farthest track point and Año Nuevo. A daily transit speed was calculated using the location with the highest Argos-assigned quality from each day, based on the great-circle distance between the daily locations and the time elapsed. When there was more than 1 location of equal quality, the location with the greatest time separation from the previous daily location was used.

Diving behavior. Mean depth, duration, surface interval, and the percent of time spent diving were calculated for each diving record. Dives were classified by visual inspection according to their shapes as described in Le Boeuf et al. (1992, 1993, 1996, 2000). Type A dives are $\mathrm{V}$-shaped dives with no distinct bottom time, and are assumed to represent transit or traveling dives. Type $\mathrm{C}$ dives, with a descending drift segment characterized by a dramatic reduction in descent rate, are potentially associated with food processing (Crocker et al. 1997). Type D dives with a distinct bottom time characterized by multiple vertical excursions are assumed to represent pelagic foraging. Type $\mathrm{E}$ dives with flat bottoms may represent either bathymetrically constrained traveling along the ocean bottom, or continental shelf or benthic foraging. The proportions of these dive types exhibited were calculated for all females.

Bout lengths were calculated for presumed transit and foraging dives. A 'bout criteria' or the minimum state duration required to interrupt a bout of behavior was determined using log-survivorship analysis (Slater \& Lester 1982) for each seal, and was similar to 2 times the mean dive duration for each dive type by each female. Four out of the 30 females analyzed in this fashion did not yield distinct inflection points on log survivorship plots. For these 4 females, bout criteria of 2 times the mean dive duration of that dive type were used. A mean bout duration for foraging and transit dives was calculated for each female. Mean travel time between prey patches was estimated as the mean bout length of transit dives. Mean prey patch residence time was estimated as the mean bout length of foraging dives.

Natality impacts. Natality was estimated based on the number of tagged individual females sighted during the breeding season that gave birth to pups. Daily censuses of all Año Nuevo harems were made during the breeding seasons in 1986 to 1999 and known females were recorded. A female was considered to have skipped breeding if she was never observed to nurse a pup during her time on shore.

Analysis. Statistics were performed using SAS v.8 with a significance level of $p<0.05$. Variables were transformed as necessary to meet the assumptions of parametric statistics. Means are presented as $\pm 1 \mathrm{SD}$.

\section{RESULTS}

Complete satellite tracks were obtained for 6 out of 9 females tracked in 1998; 2 tags worked intermittently, and 1 female's tag failed after $2 \mathrm{wk}$. This female did not return to Año Nuevo. Complete time-depth records were obtained for 7 of the females. Mass gain, trip duration, and changes in body composition measurements over the period at sea were obtained from 8 females.

\section{Foraging success and trip duration}

Sample sizes, rates of mass gain and trip durations for the different El Niño are shown in Table 1. Rates of mass gain in 1998 were the lowest ever measured $\left(0.29 \pm 0.36 \mathrm{~kg} \mathrm{~d}^{-1}\right)$, with one female losing mass at a rate of $0.44 \mathrm{~kg} \mathrm{~d}^{-1}$. Rates of mass gain varied significantly between El Niño class (ANOVA $F_{2,60}=21.3$, $\mathrm{p}<0.01$ ), being lower during a strong El Niño (Tukey's HSD, $p<0.05$ ). Rates of mass gain were not significantly different between weak and no El Niño years $(p>0.05)$. Foraging trip durations were significantly greater during strong El Niño years (Tukey's HSD, $\mathrm{p}<$ 0.05 ) and shorter during weak El Niño years (ANOVA, $F_{2,60}=17.6, \mathrm{p}<0.001$; Tukey's HSD, $\left.\mathrm{p}<0.05\right)$. When individual data was pooled from all years, foraging trip duration was significantly negatively correlated with rate of mass gain during the trip $(\mathrm{r}=-0.54, \mathrm{n}=61, \mathrm{p}<$ 0.01 ). When mean annual values were plotted, trip 
Table 1. Mirounga angustirostris. Mean $( \pm \mathrm{SD})$ foraging success, trip duration, diving behavior, and transit rates during spring foraging trips of female seals. El Niño strength was classified based on the Japan Meteorological Agency sea surface temperature anomaly index. Strong El Niño: 1983 and 1998; weak El Niño: 1987, 1988 and 1992; no El Niño: 1984 to 1986, 1989 to 1991 and 1993 to 1997

\begin{tabular}{|lccccccc|}
\hline & $\begin{array}{c}\text { Mass gain } \\
\left(\mathrm{kg} \mathrm{d}^{-1}\right)\end{array}$ & $\begin{array}{c}\text { Adipose } \\
\text { tissue } \\
(\%)\end{array}$ & $\begin{array}{c}\text { Trip } \\
\text { duration } \\
(\mathrm{d})\end{array}$ & $\begin{array}{c}\text { Type D } \\
\text { dives } \\
(\%)\end{array}$ & $\begin{array}{c}\text { Type A } \\
\text { dives } \\
(\%)\end{array}$ & $\begin{array}{c}\text { Type C } \\
\text { dives } \\
(\%)\end{array}$ & $\begin{array}{c}\text { Daily } \\
\text { transit rate } \\
\left(\mathrm{m} \mathrm{s} \mathrm{s}^{-1}\right)\end{array}$ \\
\hline Strong El Niño & $\begin{array}{c}0.32 \pm 0.30 \\
(\mathrm{n}=12)\end{array}$ & $\begin{array}{c}24.2 \pm 2.4 \\
(\mathrm{n}=8)\end{array}$ & $\begin{array}{c}99.7 \pm 16.9 \\
(\mathrm{n}=12)\end{array}$ & $\begin{array}{c}39.3 \pm 15.0 \\
(\mathrm{n}=7)\end{array}$ & $\begin{array}{c}51.1 \pm 15.9 \\
(\mathrm{n}=7)\end{array}$ & $\begin{array}{c}4.1 \pm 0.9 \\
(\mathrm{n}=7)\end{array}$ & $\begin{array}{c}0.65 \pm 0.11 \\
(\mathrm{n}=6)\end{array}$ \\
Weak El Niño & $\begin{array}{c}1.03 \pm 0.25 \\
(\mathrm{n}=8)\end{array}$ & $\mathrm{n} / \mathrm{a}$ & $\begin{array}{c}70.1 \pm 8.5 \\
(\mathrm{n}=8)\end{array}$ & $\mathrm{n} / \mathrm{a}$ & $\mathrm{n} / \mathrm{a}$ & $\mathrm{n} / \mathrm{a}$ & $\mathrm{n} / \mathrm{a}$ \\
No El Niño & $\begin{array}{c}0.94 \pm 0.31 \\
(\mathrm{n}=43)\end{array}$ & $\begin{array}{c}28.4 \pm 2.8 \\
(\mathrm{n}=34)\end{array}$ & $\begin{array}{c}80.2 \pm 10.8 \\
(\mathrm{n}=43)\end{array}$ & $\begin{array}{c}59.4 \pm 7.3 \\
(\mathrm{n}=23)\end{array}$ & $\begin{array}{c}27.2 \pm 6.7 \\
(\mathrm{n}=23)\end{array}$ & $\begin{array}{c}7.2 \pm 1.2 \\
(\mathrm{n}=23)\end{array}$ & $\begin{array}{c}0.71 \pm 0.23 \\
(\mathrm{n}=21)\end{array}$ \\
\hline
\end{tabular}

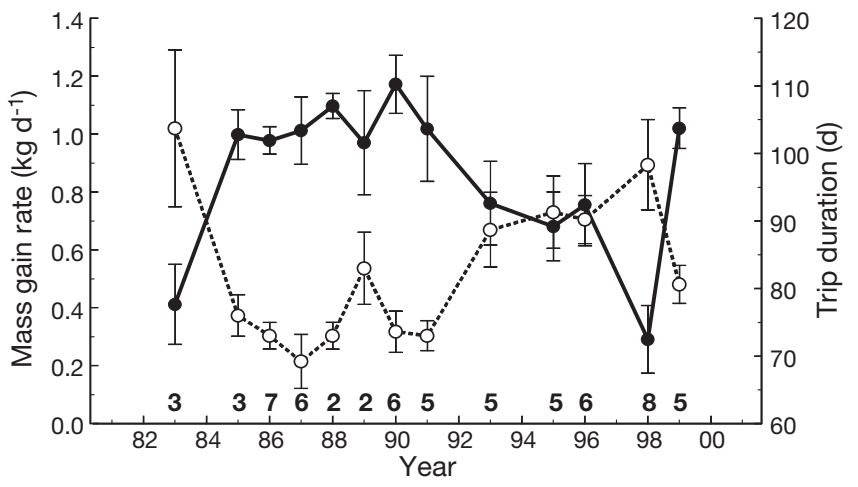

Fig. 1. Mirounga angustirostris. Mean annual rates of mass gain and spring foraging trip duration in female seals from Año Nuevo. Error bars: $1 \mathrm{SD} ; \bullet$ : rates of mass gain; $\mathrm{O}$ : foraging trip duration; annual sample sizes in bold

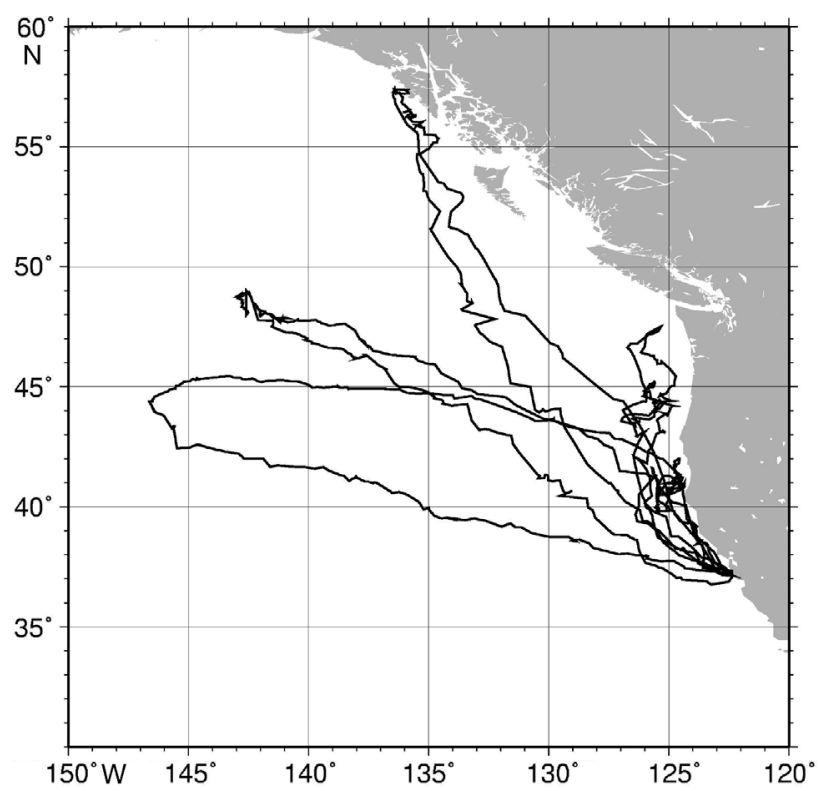

Fig. 2. Mirounga angustirostris. Satellite tracks of foraging migrations of female seals from Año Nuevo, California during spring 1998. Track lines were drawn by connecting all accepted locations; locations were filtered using a maximum transit speed of $3.0 \mathrm{~m} \mathrm{~s}^{-1}$ duration appeared to closely track rates of mass gain (Fig. 1), and the mean annual values of these variables were significantly correlated $(\mathrm{r}=-0.92, \mathrm{n}=13, \mathrm{p}<$ 0.01). The one strong exception to this pattern was the 1998 female ('Sto') that was losing mass. This female hauled out after $64 \mathrm{~d}$, one of the shorter foraging trips exhibited in any year.

During 1998, females returned with lower average adipose tissue proportions than in other years (Table 1). Mean body composition of returning females (24.2 \pm $2.4 \%$ adipose tissue, $\mathrm{n}=8$ ) was significantly lower that that of females in other years $(28.4 \pm 2.8 \%$ adipose tissue, $\mathrm{n}=34)(t=4.25, \mathrm{df}=40, \mathrm{p}<0.01)$.

\section{Location, movement, and behavior}

Satellite tracks of females in 1998 (Fig. 2) revealed typical wide coverage of the northeast Pacific Ocean. Mean maximum distance traveled was not significantly different in $1998(1841 \pm 827 \mathrm{~km})$ than in data pooled from 1995 to 1996 and 1999 (2270 \pm 603 km;

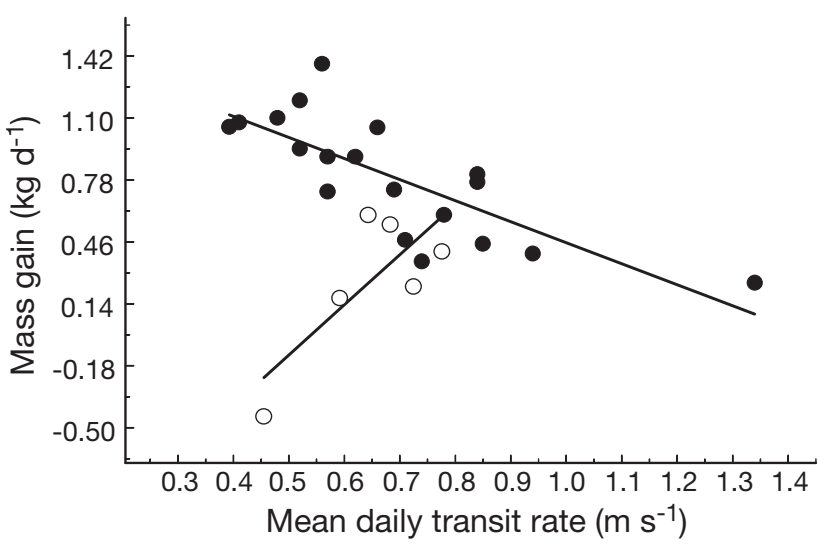

Fig. 3. Mirounga angustirostris. Relationship of mean daily transit rates to mass gain. Daily transit rates were calculated based on the highest Argos-assigned quality daily location.

-: females foraging in non-El Niño years $(\mathrm{r}=-0.77, \mathrm{p}<0.01)$; $\mathrm{O}$ : females foraging in spring $1998(\mathrm{r}=0.77, \mathrm{p}<0.01)$ 
$t=-1.28, \mathrm{df}=17, \mathrm{p}>0.05)$. Mean daily transit rates were similar in $1998\left(0.65 \pm 0.110 \mathrm{~m} \mathrm{~s}^{-1}\right)$ to other years $\left(0.71 \pm 0.23 \mathrm{~m} \mathrm{~s}^{-1}, t=0.685, \mathrm{df}=25, \mathrm{p}>0.05\right)$. The relationship between mean daily transit rates and rates of mass gain is shown in Fig. 3. In non-El Niño years there was a strong negative correlation between rates of transit and mass gain ( $\mathrm{r}=-0.77, \mathrm{n}=21, \mathrm{p}<0.01)$. A different relationship was observed in 1998. During El Niño there was a trend toward positive correlation between transit rates and rates of mass gain that was marginally statistically significant $(\mathrm{r}=0.77, \mathrm{n}=6$, $\mathrm{p}=0.07)$.

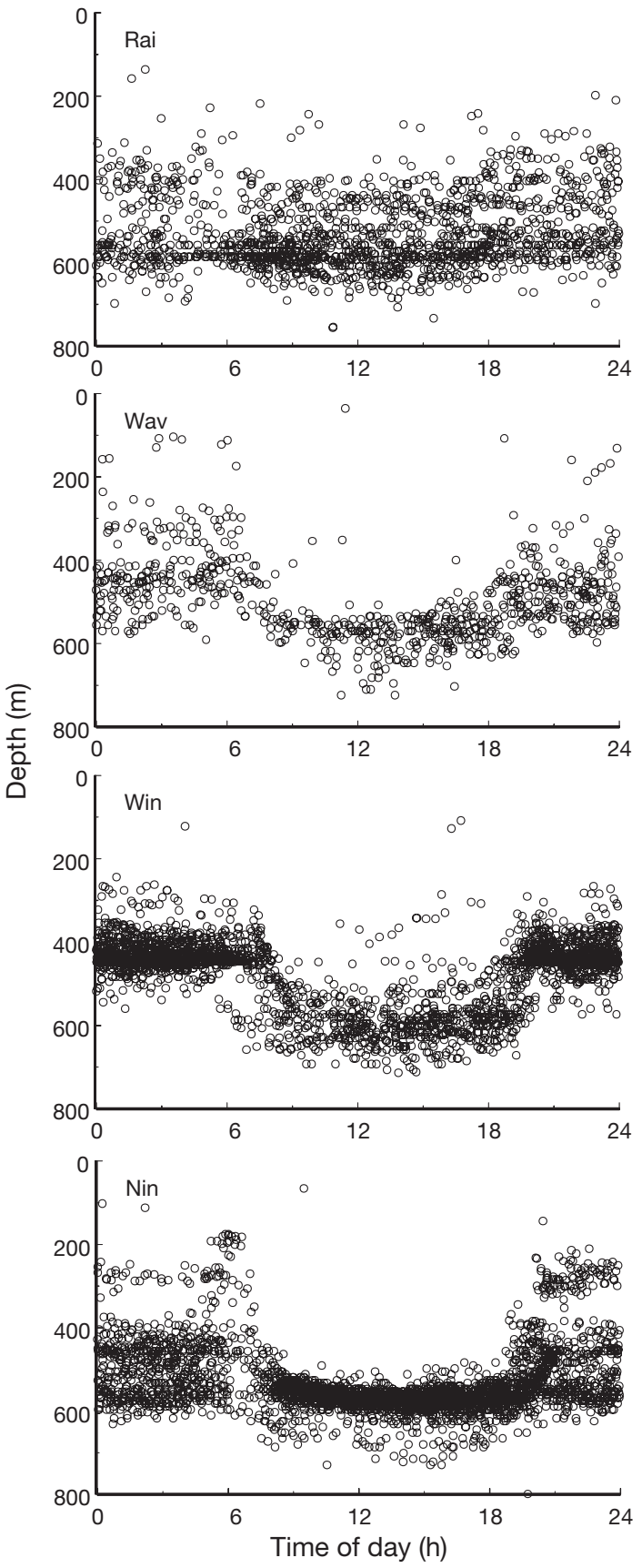

Mean diving depth, duration, and surface intervals were not significantly different in 1998 compared to other years. Presumed foraging (Type D) dives exhibited the strong diel pattern in 1998 females that was evident in females from other years (Fig. 4) (Le Boeuf et al. 1996) with the exception of 2 females ('Rai' and 'Sun'), who for part of their records spent significant parts of the day foraging higher in the water column than is typical. There was no obvious geographical variable correlated to this behavior, with one female foraging close to the coast $\left(126^{\circ} \mathrm{W}\right.$, 'Rai') and another foraging much farther out in the pelagic environment $\left(143^{\circ} \mathrm{W}\right.$, 'Sun').
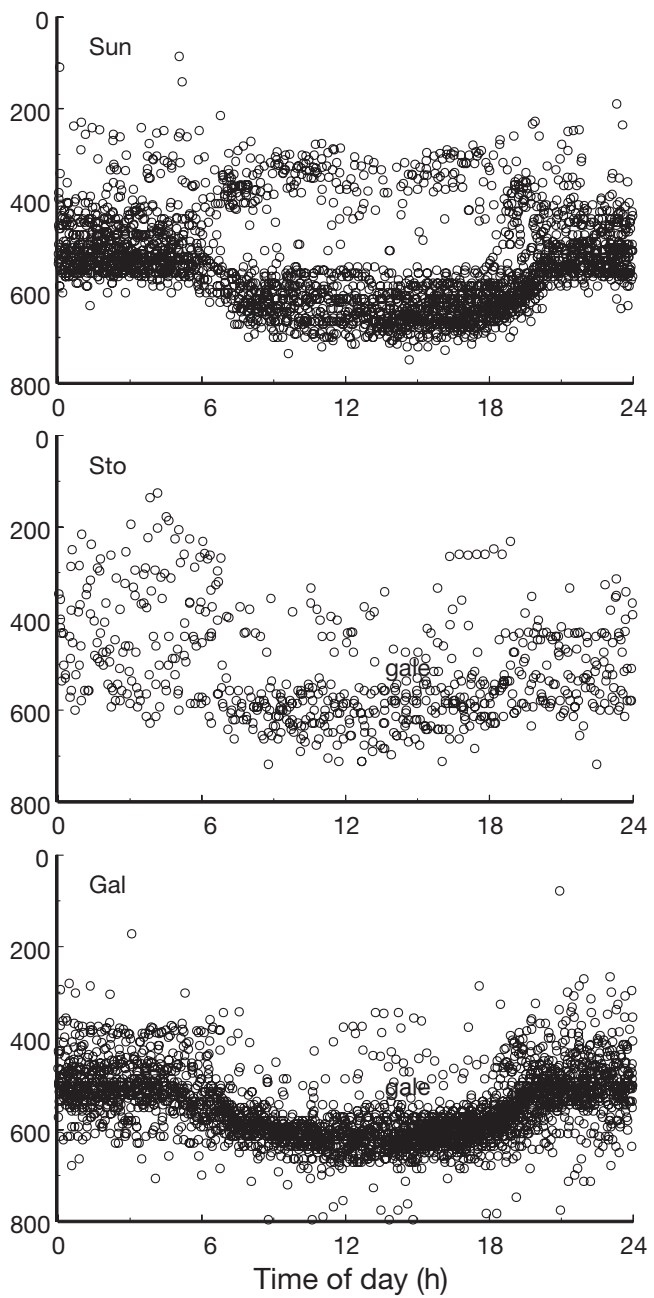

Fig. 4. Mirounga angustirostris. Diel patterns of maximum depth of foraging dives (Type D) in females during spring 1998 foraging trips. 'Rai' and 'Sun' exhibited unusually shallow midday feeding. Note comparative scarcity of foraging dives in 'Wav' and 'Sto'; 'Sto' was in negative energy balance 
The proportions of dive types in the diving records of females in 1998 and non-El Niño years are shown in Table 1. Females exhibited significantly greater proportions of presumed transit (Type A) dives in 1998 (Mann-Whitney rank sum test, $T=185.0, \mathrm{n}=7.23, \mathrm{p}<$ 0.01 ) and significantly lesser proportions of foraging dives (Type D) $(t=4.9, \mathrm{df}=28, \mathrm{p}<0.01)$. On average there was an $88 \%$ increase in the number of transit dives and a $34 \%$ reduction in foraging dives during 1998. The proportion of drift dives (Type C) was significantly lower during 1998 in comparison to nonEl Niño years (Mann-Whitney Rank sum test, $T=28.0$, $\mathrm{n}=7.23, \mathrm{p}<0.01$ ), on average a $43 \%$ reduction. When data from all years was pooled there was a significant positive correlation between the proportion of foraging dives and rate of mass gain $(n=28, r=0.71, p<0.01)$.

The temporal patterning of dive types into bouts was significantly different during El Niño. Travel times between prey patches were significantly greater in $1998(175 \pm 29 \mathrm{~min})$ than in other years $(115 \pm 23 \mathrm{~min})$ (Mann-Whitney rank sum test, $T=146.5, \mathrm{n}=7.19$, $\mathrm{p}<$ 0.01). Patch residence time was significantly less in 1998 (145 $\pm 30 \mathrm{~min})$ than during non-El Niño years $(212 \pm 33)(t=4.1, \mathrm{df}=24, \mathrm{p}<0.01)$. There was a significant positive relationship between patch residence time and travel time in non-El Niño years (patch residence time $=82+1.1$ (travel time), $F_{1,26}=32.7, \mathrm{r}^{2}=0.69$, $\mathrm{p}<0.01$ ) (Fig. 5). This relationship was not present in 1998. In order to compare these variables with a measure of foraging success, a ratio of patch residence time to travel time was calculated for each female and compared to rates of mass gain. The ratio of mean patch

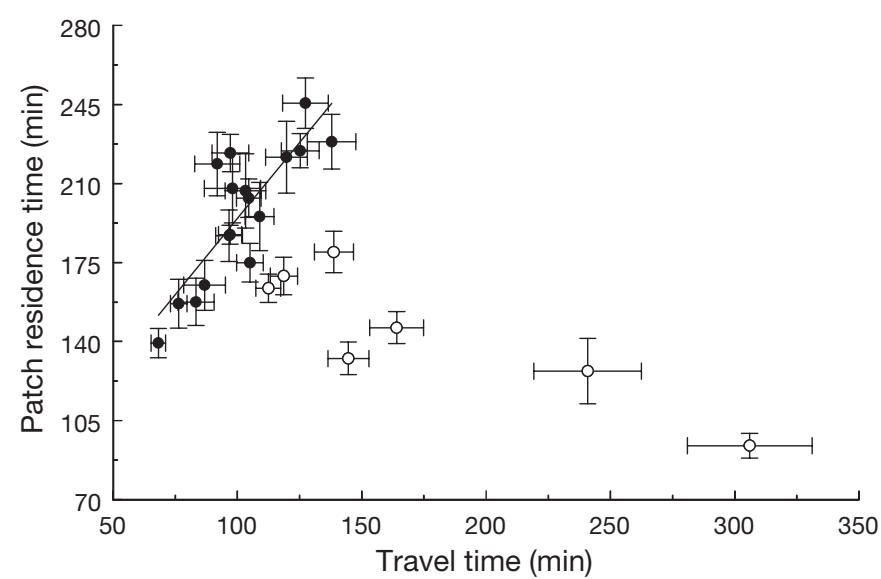

Fig. 5. Mirounga angustirostris. Relationship of behaviorally estimated patch residence time to travel time between patches during spring foraging trips. Each data point represents mean value $( \pm \mathrm{SE})$ for a female's entire foraging trip. Bout criteria were determined using log-survivorship analysis. Patch residence was calculated as the mean bout duration of Type D dives. Travel time was calculated as the mean bout duration of Type A dives. •: females foraging in non-El Niño years; O: females foraging during 1998

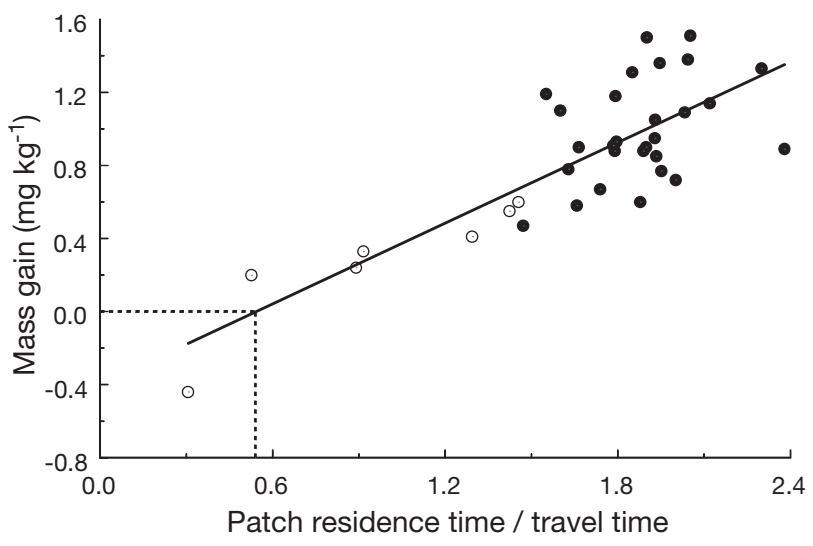

Fig. 6. Mirounga angustirostris. Relationship of behaviorally estimated foraging parameters (ratio of patch residence time to travel time) to foraging success (mass gain). Regression line: $y=-0.40+0.74 x, r^{2}=0.66, p<0.01$; dotted line: predicted ratio of patch residence to travel time required for positive energy balance

residence time to mean travel time in non-El Niño years was $2.0 \pm 0.2$ (range: 1.5 to 2.4 ). During 1998, the ratio of these means was significantly lower than in non-El Niño years $(1.0 \pm 0.4 ; t=7.7$, df $=22$, $\mathrm{p}<0.01)$. This metric was a significant predictor of rates of mass gain in foraging females $\left(\mathrm{r}^{2}=0.66, \mathrm{p}<0.01\right)$ (Fig. 6).

\section{Water temperature}

Mean SST was calculated from each female's diving record and compared to data from females in 1996 and 1999. The relationship between mean SST and rates of mass gain is shown in Fig. 7. Increased foraging suc-

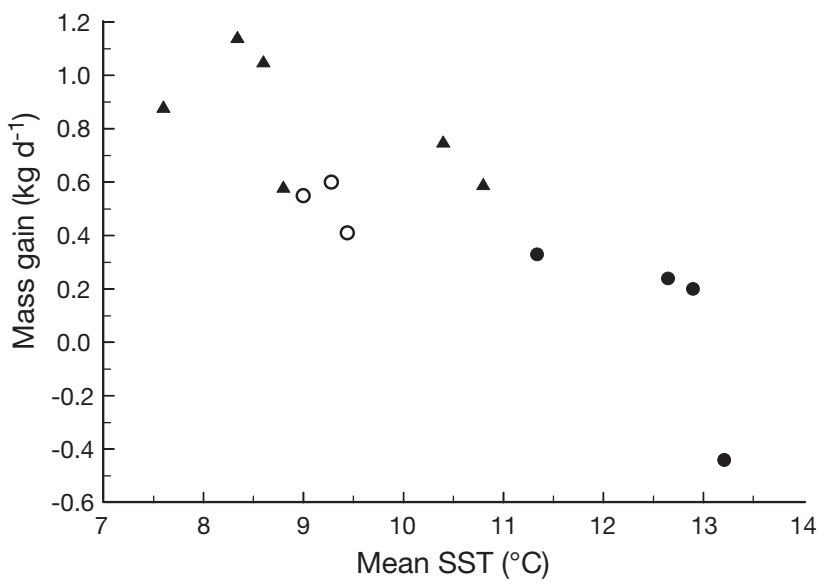

Fig. 7. Mirounga angustirostris. Mean sea surface temperature (SST) for entire foraging record measured using TDRs plotted against rates of mass gain. $\mathbf{\Lambda}$ : females from non-El Niño years; O: females from 1998 with rates of mass gain within 2 SD of mean from all non-El Niño years; $\bullet$ : females with rates of mass gain less than 2 SD below mean from all non-El Niño years 
cess was associated with colder surface water temperatures. Among the 1998 records, females that had 'normal' rates of mass gain while foraging, defined as within 2 standard deviations of the non-El Niño mean, foraged in areas with significantly cooler surface waters $\left(9.2^{\circ} \mathrm{C}\right)$ than females with lower than normal rates of mass gain $\left(12.5^{\circ} \mathrm{C} ; t=6.6, \mathrm{df}=5, \mathrm{p}<0.01\right)$.

\section{Natality impacts}

Natality during the 1999 breeding season (following El Niño) was $87 \%$, the lowest ever recorded at the colony. Natality from 1986-1998 averaged $96.5 \pm 0.6 \%$.

\section{DISCUSSION}

These data demonstrate strong impacts of the 1997-98 El Niño event on the foraging behavior of female northern elephant seals. Foraging was evidently more difficult as reflected in dramatically lower rates of mass gain. Our data confirmed that the immediate ecological impact of the 1997-98 El Niño was not limited to the nearshore coastal margin, but extended far out into the North Pacific Ocean. Females spent longer amounts of time finding prey patches and exhibited reduced times using those patches. These changes resulted in markedly reduced foraging success compared to typical years, a result consistent with observations during the strong 1982-83 El Niño. This resulted in both significantly lower rates of mass gain, as well as significantly lower adipose tissue proportions at the end of the spring foraging trip. Reductions in foraging success were not evident during weak El Niño events.

The ecological mechanisms underlying foraging difficulties in 1998 are less clear. Elephant seals feed at great depths far from the coastal upwelling processes most closely associated with ENSO impacts. Foraging difficulties could have resulted from a number of changes including reductions in prey abundance, alterations in prey distribution or patch characteristics, and/or alterations in the cues used by the seals to locate prey. Although these same factors have been suggested to underlie foraging difficulties associated with coastal upwelling regimes (Trillmich \& Ono 1991), our data suggests that some or all of these alterations extended into the northeast Pacific.

Northern elephant seals feed primarily on mesopelagic squid, elasmobrachs, and myctophid fish (Antonelis et al. 1987). As foraging difficulties in the present study did not appear to be associated with foraging location, explanations based on reduced prey availability would imply reductions in squid abun- dance throughout the northeast Pacific Ocean. Concurrent investigations and those during previous ENSO events have revealed effects on species abundance, diversity and range that varied with species and location. Recent investigations have shown that variability in recruitment of several squid species is at least partially explained by environmental variability and may be linked to the ENSO cycle (Rodhouse 2001). The 1987 El Niño was associated with an extraordinary abundance of cephalopod paralarvae in the eastern tropical Pacific, coincident with the $29^{\circ}$ surface isotherm (Vecchione 1999). As adult female elephant seals are thought to predominantly eat larger adult individuals of cephalopods, there was probably not sufficient lag time for potential El Niño effects on recruitment to have impacted abundance of these prey in the areas used by the females.

Simulations of biomass trajectories from bottom-up pulses from ENSO cycles have suggested significant lag times as effects move up trophic levels and that pelagic marine mammals should be minimally affected (Watters et al. 2003). However, the conditions associated with the onset of the El Niño event may have also had effects. For example, the growth and feeding of salmon preying on squid in the Subarctic Current were affected during the spring and summer of 1997 (Kaeriyama et al. 2000). The unusual pattern of feeding higher in the water column during midday, as seen in 2 female elephant seals, suggests that they might have used alternative prey resources compared to typical females. This lack of a typical diel pattern of foraging depth had not been seen in any adult female in previous or subsequent investigations (e.g. Le Bouef at al. 1993, 2000).

Alternatively, the oceanographic features that help to create prey patches may be altered during El Niño events. Marine predators may rely on oceanographic features, such as frontal systems, thermocline depth, and bathymetry to concentrate or aggregate prey (Hui 1979, 1985, Schneider 1982, Springer \& Roseneau 1985, Haney 1986, 1991, Winn et al. 1986, Ainley \& DeMaster 1990, Reilly 1990, Boyd \& Arnbom 1991, Hunt et al. 1992, van Franeker 1992, Whitehead et al. 1992, Elphick \& Hunt 1993, Kenney et al. 1995, Mehlum et al. 1996, Hunt 1997). These aggregations may be essential to enable energy efficient foraging strategies in the oceanic environment. As sea surface temperature and the position of frontal systems change as a result of El Niño effects in the North Pacific Ocean, the oceanographic features that help to determine prey patch characteristics may be altered with resulting impacts on foraging economics. A previous investigation on seabirds found that forage resource availability fluctuated daily in association with fine scale variation in SST during El Niño (Peck et al. 2004). The migration 
tracks of the 2 female elephant seals with the greatest foraging success ('Wav' and 'Sun') covered areas associated with the meandering transition zone chlorophyll front (TZCF). This feature exhibited unusual latitudinal movement during the 1997-98 El Niño, which was hypothesized to have created regions of convergence which may have improved foraging habitat for apex predators working the front (Polivina et al. 2001). These 'successful' females also foraged in the coldest average surface waters of any of the El Niño females.

In addition, the cues that marine predators use to find prey patches may be altered. Preliminary analysis suggests that female foraging locations may be associated with thermal discontinuities (D. Crocker \& D. Costa unpubl. data). Elephant seals exhibit high rates of turning or movement along high temperature gradients (Boehlert et al. 2001). Alterations in SST and the depressed thermocline associated with El Niño may reduce predator ability to locate prey patches, independent of prey abundance. This last idea is supported by both the lack of increased foraging range and strong positive relationship of foraging success to transit rates evident in 1998. Given the tremendous migration ability evident in this species, it is puzzling that the least successful females, including one that was in negative energy balance, would not attempt to extend their foraging range and instead continue to forage in an unsuccessful area. Previous investigations on foraging site fidelity in females have suggested a fidelity to initial migration direction, followed by variability, presumably in response to ephemeral oceanographic conditions and prey locations ( Le Boeuf et al. 2000). One possibility is that females were responding to inappropriate oceanographic cues while searching for prey.

Female elephant seals appear to compensate for reduced foraging success by increasing time spent at sea. For example, by far the longest post-breeding trips to sea occurred in the 2 severe El Niño years, 1983 and 1998. From this perspective, El Niño event duration is probably as important as event intensity in determining impacts on subsequent reproduction. Females have an additional 8 mo foraging period from June to December to complete their recovery from the previous year's breeding. The duration of this second foraging trip is most likely limited by gestational progress. By increasing the duration of the pre-implantation foraging trip, females can insure that they have regained sufficient resources before beginning gestation. Since most females foraging during El Niño were still gaining mass at a reduced level this event would be an unlikely cause of mortality.

The issue is what impacts this period of reduced resource recovery has on subsequent breeding attempts. Previous investigations have shown strong effects of maternal mass and body composition on subsequent reproductive investment (Crocker et al. 2001). All of the recovered females that were in positive energy balance were observed to breed successfully in 1999. The female in negative energy balance was not seen again after the molt and was presumed to have skipped breeding. Natality rates have been extremely high and invariant at the Año Nuevo rookery (94 to $97 \%$ ) (Le Bouef \& Reiter 1991). The reduction in natality rate in 1999 is likely a response to extreme foraging difficulties among 7 to $10 \%$ of the breeding age females. Similarly, the mean weaning weight of pups born in 1999 was the lowest ever recorded after a $20 \mathrm{yr}$ decline in mean annual weaning weights (Le Boeuf \& Crocker 2005). Although this reduction in natality probably does not itself have important demographic consequences, it likely contributed to the reduction in reproductive success associated with decreased juvenile survival evident during the 1982-83 El Niño. This natality impact was not evident at Año Nuevo during the breeding season following the 1983 El Niño (Le Boeuf \& Reiter 1991), but was observed at the nearby South Farallon Islands rookery (Huber et al. 1991). The most likely age classes to be effected by reduced foraging success are smaller, younger females, particularly those attempting to breed for the first time. The increase in age of first reproduction exhibited during the 1982-83 El Niño (Le Boeuf \& Reiter 1991) may have resulted from foraging difficulties like those described in the present study.

The ability to increase time spent foraging in response to reduced rates of success is one component of a foraging strategy that utilizes dispersed, patchy food resources over a large spatial and temporal scale. This protracted foraging period is a key component of a life history strategy that minimizes the period of parental care and allows long-term accrual of breeding resources. This pattern may serve to buffer these predators from short-term changes in prey availability and prevent the large scale reproductive failures seen in other species of coastal pinnipeds and seabirds during strong El Niño events. However, effects like reduced natality, increased age of first reproduction, and reduced juvenile survival may have cumulative effects on cohort reproductive success that have demographic consequences. Persistence in warm SST, associated in part with the frequency of strong El Niño events, may have cumulative impacts on growth and resources available for breeding. For example, impacts on pup production in Antarctic fur seals were only observed under persistent high SST levels, affecting females over time scales longer than their breeding cycle (Forcada et al. 2005). Impacts of long-term climate changes, like those associated with the Pacific decadal oscillation (Le Boeuf \& Crocker 2005), may amplify the short term impact of El Niño events. 
The increased variation in success during the 1998 spring foraging trip helped to reveal an important functional relationship between patch characteristics and foraging success. The relationship obtained in this study implies that, on average, northern elephant seal females need to spend at least half as much time attempting to forage in patches as they spend looking for those patches to stay in positive energy balance. To achieve more typical rates of mass gain the ratio of patch residence to travel needs to be closer to 2 . This strong relationship to rates of mass gain gives credence to this approach of estimating patch characteristics based on diving behavior, and provides a unique insight into how prey distribution impacts foraging economics in this species. The return to more typical foraging parameters in 1999 suggests that despite the unusual length of the 1997-98 El Niño, the ecological impacts in the northeast Pacific that affected elephant seal foraging did not extend into the following year. The reduced frequency of presumed pelagic foraging dives and food processing dives, the increased frequency of presumed traveling dives, and the strong association of these changes with reduced foraging success in 1998 provides further support for the putative functions of each one of these dive types.

El Niño events occur intermittently over the lifetime of a breeding female, with strong events occurring perhaps once in a reproductive lifespan. In addition to selecting for the ability to increase foraging effort prior to implantation, this unpredictable reduction in food resources may select for females that maintain larger body reserves than required for successful provisioning of the pup during breeding. Larger females wean larger pups (Reiter et al. 1981, Crocker et al. 2001), but it has been difficult to show offspring survival advantages that are derived from this increased parental investment. Large body size may help older females maintain high rates of natality and weaning success in years with reduced prey availability.

Acknowledgements. This research was supported by NOAA grant \# NA77RJ0453. D.E.C. was supported by grants from the Packard Foundation and the Office of Naval Research. We thank the Año Nuevo Park Service and Rangers for logistical support. This work was completed under NMFS Marine Mammal permit \#836. All procedures were approved by the UCSC Chancellor's Animal Research Committee.

\section{LITERATURE CITED}

Ainley DG, DeMaster DP (1990) The upper trophic levels in polar marine ecosystems. In: Smith WO (ed) Polar oceanography B, chemistry, biology, and geology. Academic Press, San Diego, p 599-630

Antonelis GA, Lowry MS, DeMaster DP, Fiscus CH (1987) Assessing northern elephant seal feeding habits by stomach lavage. Mar Mamm Sci 3:308-322
Antonelis GA, Lowry MS, Fiscus CH, Stewart BS, DeLong RL (1994) Diet of the northern elephant seal. In: Le Bouef BJ, Laws RM (eds) Elephant seals: population ecology, behavior, and physiology. Academic Press, Berkeley, p 211-223

Arntz W, Pearcy WG, Trillmich F (1991) Biological consequences of the 1982-83 El Niño in the Eastern Pacific. In: Trillmich F, Ono K (eds) Pinnipeds and El Niño: responses to environmental stress. Springer Verlag, Berlin, p 22-44

Barber RT, Chavez FP (1983) Biological consequences of El Niño. Science 222:1203-1210

Barber RT, Chavez FP (1986) Ocean variability in relation to living resources during the 1982-83 El Niño. Nature 319: 279-285

Boehlert GW, Costa DP, Crocker DE, Green P, O'Brien T, Levitus S, Le Boeuf BJ (2001) Autonomous pinniped environmental samplers; using instrumented animals as oceanographic data collectors. J Atmos Oceanic Technol 18:182-189

Boyd IL, Arnbom T (1991) Diving behavior in relation to water temperature in the southern elephant seal: foraging implications. Polar Biol 11:259-266

Briggs GD, Hendrickson RV, Le Boeuf BJ (1975) Ketamine immobilization of northern elephant seals. J Am Vet Med Assoc 167:546-548

Brinton E, Loeb VJ, Macaulay MC, Shulenberger E (1987) Variability of Euphausia superba populations near Elephant Island and the South Shetlands: 1981 vs. 1984. Polar Biol 7:345-362

Brodeur RD, Percy WG (1992) Effects of environmental variability on trophic interactions and food web structure in a pelagic upwelling ecosystem. Mar Ecol Prog Ser 84: 101-119

Congleton CA (1980) Navigational applications of plane and spherical trigonometry. Cornell Maritime Press, Centreville, MD

Crocker DE, Le Boeuf BJ, Costa DP (1997) Drift diving in female northern elephant seals: implications for food processing. Can J Zool 75:27-39

Crocker DE, Williams JD, Costa DP, Le Boeuf BJ (2001) Maternal traits and reproductive effort in northern elephant seals. Ecology 82:3451-3555

Elphick CS, Hunt Jr GL(1993) Variations in the distributions of marine birds with water mass in the northern Bering Sea. Condor 95:33-44

Enfield DB (2001) Evolution and historical perspective of the 1997-1998 El Niño-Southern oscillation event. Bull Mar Sci 69:7-25

Forcada J, Thrathan PN, Reid K, Murphy EJ (2005) The effects of global climate variability in pup production of Antarctic fur seals. Ecol 86:2408-2417

Gales NJ, Burton HR (1987) Ultrasonic measurement of blubber thickness of the southern elephant seal, Mirounga leonina (Linn). Aust J Zool 35:207-217

Haney JC (1986) Seabird segregation at Gulf Stream frontal eddies. Mar Ecol Prog Ser 28:279-285

Haney JC (1991) Influence of pycnocline topography and water-column structure on marine distribution of alcids (Aves:Alcidae) in Anadyr Strait, northern Bering Sea, Alaska. Mar Biol 110:419-435

Heywood RB, Everson I, J Pridle J (1985) The absence of krill from the South Georgia, zone, winter 1983. Deep-Sea Res 32:369-378

Huber HR, Beckham C, Nisbet J (1991) Effects of the 1982-83 El Niño on northern elephant seals of the South Farallon Islands, California. In: Trillmich F, Ono K (eds) Pinnipeds and El Niño: responses to environmental stress. Springer Verlag, Berlin, p 219-233 
Hui CA (1979) Undersea topography and distributions of dolphins of the genus Delphinus in the southern California bight. J Mammal 60:521-527

Hui CA (1985) Undersea topography and the comparative distributions of two pelagic cetaceans. Fish Bull 83:472-475

Hunt Jr GL (1997) Physics, zooplankton, and the distribution of least auklets in the Bering Sea: a review. ICES J Mar Sci 54:600-607

Hunt GL, Heinemann D, Everson I (1992) Distribution and predator-prey interactions of macaroni penguins, Antarctic fur seals, and Antarctic krill near Bird Island, South Georgia. Mar Ecol Prog Ser 86:15-30

Kaeriyama M, Megumi N, Mami Y, Hiroshi U and 5 others (2000) Feeding ecology of sockeye and pink salmon in the Gulf of Alaska. NPAFC Bull 2:55-63

Karl DM, Leteller R, Hebel D, Tupas L, Dore J, Christian J, Winn C (1995) Ecosystem changes in the North Pacific subtropical gyre attributed to 1991-92 El Niño. Nature 373:230-233

Kenney RD, Winn HE, Macaulay MC (1995) Cetaceans in the Great South Channel, 1979-1989: right whale (Eubalaena glacialis). Cont Shelf Res 15:385-414

Kerr RA (1998) Models win big in forecasting El Niño. Science 280:522-523

Le Boeuf BJ, Crocker DE (2005) Ocean climate and seal condition. BMC Biology 3:9

Le Boeuf BJ, Reiter J (1991) Biological effects associated with El Niño, Southern Oscillation 1982-83, on northern elephant seals breeding at Año Nuevo, California. In: Trillmich $\mathrm{F}$, Ono K (eds) Pinnipeds and El Niño: responses to Environmental Stress. Springer Verlag, Berlin, p 206-218

Le Boeuf BJ, Costa DP, Huntley AC, Feldkamp SD (1988) Continuous, deep diving in female northern elephant seals, Mirounga angustirostris. Can J Zool 66:446-458

Le Boeuf BJ, Crocker DE, Blackwell SB, Morris PA, Thorson $\mathrm{PH}$ (1993) Sex differences in the diving and foraging behavior of northern elephant seals. In: Boyd IL (ed) Recent advances in marine mammal science. Symp Zool Soc Lond 66:149-178

Le Boeuf BJ, Naito Y, Asaga T, Crocker DE, Costa DP (1992) Swim speed in a female northern elephant seal: metabolic and foraging implications. Can J Zool 70:786-795

Le Boeuf BJ, Morris PA, Blackwell SB, Crocker DE, Costa DP (1996) Diving behavior of juvenile northern elephant seals. Can J Zool 74:1632-1644

Le Boeuf BJ, Crocker DE, Costa DP, Blackwell SB, Webb PM, Houser DS (2000) Foraging ecology of northern elephant seals. Ecol Monogr 70:353-382

McPhaden MJ (1999) Genesis and evolution of the 1997-98 El Niño. Science 283:950-954

Mehlum F, Hunt GL, Klusek Z, Decker MB, Nordlund N (1996) The importance of prey aggregations to the distribution of Brunnich's guillemots in Storfjorden, Svalbard. Polar Biol 16:537-547

Peck DR, Smithers BV, Krokenberger AK, Congdon BC (2004) Sea surface temperature constrains wedge-tailed shear-

Editorial responsibility: Otto Kinne (Editor-in-Chief), Oldendorf/Luhe, Germany water foraging success within breeding seasons. Mar Ecol Prog Ser 281:259-266

Polovina JJ, Howell E, Kobayashi DR, Seki MP (2001) The transition zone chlorophyll front, a dynamic global feature defining migration and forage habitat for marine resources. In: McKinnell SM, Brodeur RD, Hanawa K, Hollowed AB, Polovina JJ, Zhang C (eds) Pacific climate variability and marine ecosystem impacts from the tropics to the Arctic. Elsevier Science (Pergamon), Oxford, p 469-483

Raskoff KA (2001) The impact of El Niño events on populations of mesopelagic hydromedusae. Hydrobiologia 451: $121-129$

Reilly SB (1990) Seasonal changes in the distribution and habitat differences among dolphins in the eastern tropical Pacific. Mar Ecol Prog Ser 66:1-11

Reiter J, Panken KJ, Le Boeuf BJ (1981) Female competition and reproductive success in northern elephant seals. Anim Behav 29:670-687

Rodhouse PG (2001) Managing and forecasting squid fisheries in variable environments. Fish Res 54:3-8

Schneider DC (1982) Fronts and seabird aggregations in the southeastern Bering Sea. Mar Ecol Prog Ser 10:101-103

Schreiber RW, Schreiber EA (1984) Central Pacific seabirds and the El Niño Southern Oscillation: 1982 to 1983 perspective. Science 225:713-716

Slater PJB, Lester NP (1982) Minimizing errors in splitting behavior into bouts. Behavior 79:153-161

Springer AM, Roseneau DG (1985) Copepod-based food webs: auklets and oceanography in the Bering sea. Mar Ecol Prog Ser 21:229-237

Trillmich F, Ono KA (1991) Pinnipeds and El Niño: responses to environmental stress. Springer Verlag, Berlin

van Franecker JA (1992) Top predators as indicators for ecosystem events in the confluence zone and the marginal ice zone of the Weddell and Scotia seas, Antarctica, November 1988 to January 1989. Polar Biol 12:93-102

Vecchione M (1999) Extraordinary abundance of squid paralarvae in the tropical eastern Pacific Ocean during El Niño of 1987. Fish Bull 97:1025-1030

Watters GM, Olson RJ, Francis RC, Fiedler PC and 7 others (2003) Physical forcing and the dynamics of the pelagic ecosystem in the eastern tropical Pacific: simulations with ENSO-scale and global-warming climate driver. Can J Fish Aquat Sci 60:1161-1175

Webb PM, Crocker DE, Blackwell SB, Costa DP, Le Boeuf BJ (1998) Effects of buoyancy on the diving behavior of northern elephant seals. J Exp Biol 201:2349-2358

Whitehead H, Brennan S, Grover D (1992) Distribution and behavior of male sperm whales on the Scotian Shelf, Canada. Can J Zool 70:912-918

Winn HE, Price CA, Sorenson PW (1986) The distributional biology of the right whale (Eubalaena glacialis) in the Western North Atlantic. Report of the International Whaling Commision (Special Issue 10), Cambridge University Press, London

Submitted: July 9, 2002; Accepted: December 8, 2005 Proofs received from author(s): February 2, 2006 